\title{
DETERMINAN YANG BERHUBUNGAN DENGAN PREMENSTRUAL SYNDROME (PMS) PADA REMAJA PUTRI DI SMPN 7 KOTA JAMBI
}

\section{Determinants which correlate with Premenstrual Syndrome (PMS) for Adolescent Girls in SMPN 7 Jambi City}

\author{
Septa Decelita Wahyuni' ${ }^{1}$ Asparian² ${ }^{2}$ M. Dody Izhar $^{2}$ \\ ${ }^{1}$ Program Studi Ilmu Kesehatan Masyarakat FKM Universitas Jambi \\ ${ }^{2}$ Dosen Program Studi Ilmu Kesehatan Masyarakat FKM Universitas Jambi
}

\begin{abstract}
Abstrak
Premenstrual syndrome (PMS) merupakan gejala yang banyak dirasakan oleh remaja selama satu minggu sebelum menstruasi. Apabila tidak diperhatikan akan berdampak menimbulkan masalah dan produktivitas. Tujuan penelitian untuk mengetahui determinan yang berhubungan dengan PMS. Jenis penelitian yaitu rancangan penelitian cros sectional. Penelitian dilakukan di SMPN 7 Kota Jambi. Waktu penelitian dari bulan November 2017- Juni 2018. Populasinya yaitu 628 remaja putri dengan 93 sampel yang diambil menggunakan teknik stratified random sampling. Data dikumpulkan melalui wawancara menggunakan kuesioner sPAF untuk mengukur gejala PMS. Analisis data menggunaan chi square dan fisher exact test pada $\propto=5 \%$. Hasil: PMS tidak mengalami - ringan yaitu $71 \%$ dan gejala sedang hingga berat yaitu $29 \%$. Remaja putri yang mengalami usia menarche prekok sebesar $4,3 \%$, berstatus gizi gemuk sebesar $25,5 \%$, serta memiliki gejala stres sebesar 90,3\%. Hasil uji statistik yaitu tidak terdapat hubungan antara usia menarche dengan PMS dengan p-value yaitu 1,000 dengan POR 0,808. Tidak terdapat hubungan antara status gizi dan PMS dengan p-value yaitu 0,186 namun status gizi gemuk beresiko meningkatkan 2,185 PMS sedang-berat. Tidak terdapat hubungan antara stres dengan PMS pada remaja putri di SMPN 7 Kota Jambi p-value yaitu 0,276, namun stres beresiko meningkatkan 3,586 kali PMS sedang-berat. Kesimpulan: Terdapat kecenderungan gemuk dan stres dapat beresiko terhadap PMS sedang-berat. Diharapkan remaja putri mampu mengetahui siklus menstruasinya, menerapkan pola gizi seimbang dan aktif dalam memanfaatkan sarana UKS.
\end{abstract}

Kata Kunci:Premenstrual syndrome, remaja putri, status gizi, stres

\begin{abstract}
Premenstrual syndrome (PMS) is a symptom which is felt by adolescent girls around one week before menstruation. It will cause health problems and productivity issues if left untreated. The purpose is to identify which determinants that correlate with PMS. This study was conducted using cross-sectional research design, starting from November 2017 to June 2018 at SMPN 7 Kota Jambi. The population is 628 adolescent girls, with 93 samples are taken using stratified random sampling technique. Data were collected through interviews using the sPAF questionnaire to measure PMS symptoms. Data analysis was done by chi-square and fisher exact test at $\propto=5 \%$. The results showed that nothing to mild PMS symptoms by $71 \%$ and moderate to severe symptoms by $29 \%$. Early menarche age by $4,3 \%, 25,5 \%$ had fat nutritional status, and $90,3 \%$ had symptoms of stress. The result of statistic test showed that no correlation between age of menarche and PMS ( $\mathrm{p}$-value $=1,000$ and POR= 0,808 ); no correlation between nutritional status and PMS ( $\mathrm{p}$-value $=0,186$ ) but fatness increase the risk by 2,185 in moderate to severe symptoms; no correlation between stress and PMS ( $p$-value $=0.276$ ) but stress increase the risk by 3,586 in moderate to severe symptoms. Conclusion: There is a tendency for fatness and stress to increase risk for moderate to severe symptoms. It is hoped that adolescent girls will be able to know their menstrual cycle, apply a balanced nutrition pattern and actively utilize UKS.
\end{abstract}

Keywords: Premenstrual syndrome, adolescent girls, nutritional status, stress

Korespondensi: Septa Decelita Wahyuni

Email: septadeclita@gmail.com 


\section{PENDAHULUAN}

Tubuh manusia mengalami perubahan dari waktu ke waktu sejak lahir yang meliputi pertumbuhan dan perkembangan. Perubahan yang cukup mencolok terjadi ketika memasuki usia antara 9-15 tahun (remaja). Pada saat itu, mereka tidak hanya tumbuh menjadi tinggi dan lebih besar, tetapi juga terjadi perubahan di dalam tubuh yang memungkinkan untuk bereproduksi. Masa pubertas pada remaja putri ditandai dengan menarche (menstruasi pertama), perubahan psikis, dan timbulnya ciriciri kelamin sekunder seperti tumbuhnya rambut pada daerah kemaluan (pubis), pembesaran payudara ${ }^{1}$.

Menstruasi berarti meluruhnya dinding rahim beserta sel telur yang tidak dibuahi melalui vagina. Selain itu menstruasi juga dapat dijadikan sebagai parameter bahwa seorang wanita telah memasuki usia remaja dan organ reproduksinya mulai berfungsi ${ }^{2}$.

Selama menghadapi menstruasi terdapat beberapa gangguan menstruasi yaitu sindrom pramenstruasi, nyeri menstruasi, menstruasi darah menggumpal, menstruasi terlambat, serta menstruasi tidak teratur ${ }^{1}$. Data menyebutkan bahwa 80-95 persen perempuan pada usia reproduksi mengalami gejala-gejala pramenstruasi yang dapat mengganggu bebrapa aspek dalam kehidupannya ${ }^{3}$. Premenstrual syndrome (PMS) adalah sekumpulan keluhan dan gejala fisik, emosional, dan prilaku yang terjadi pada wanita reproduksi, yang terjadi secara terus menerus dalam rentang waktu 7-10 hari sebelum menstruasi ${ }^{4}$. Dari hasil penelitian sebelumnya, diketahui bahwa prevalensi premenstrual syndrome (PMS) dari seluruh dunia adalah $47,8 \%{ }^{5}$. Salah satu contoh negara yang mengalami peningkatan prevalensi PMS yaitu negara Pakistan. Kejadian premenstrual syndrome di negara Pakistan pada tahun 1996 sebanyak $41 \%$ dan meningkat pada tahun 2004 menjadi 53\%. Berbeda dengan negara Brazil dimana prevalensi premenstrual syndrome stabil dari tahun 2003-2009 yaitu sebesar 60\% Berdasarkan hal ini, dapat dikatakan bahwa kejadian premenstrual syndrome berbeda di setiap negara.

PMS merupakan masalah kesehatan umum yang paling banyak dilaporkan oleh wanita usia subur. Di Indonesia dari 260 orang wanita usia subur, ditemukan sebanyak 95\% memiliki setidaknya satu gejala sindrom pramenstruasi. Penelitian yang dilakukan di Kota Padang menunjukkan bahwa 51,8 \% siswi SMP mengalami premenstrual syndrome ${ }^{6}$. Di Kota Bogor, ditemukan bahwa seluruh responden mengalami premenstrual syndromedengan jenis keluhan ringan 32,2 \% dan keluhan sedang sampai berat $67,8 \%{ }^{7}$. Penelitian di Kabupaten Pekalongan menunjukkan bahwa 71,3\% siswi SMP mengalami PMS di SMPN $1 \mathrm{Sragi}^{3}$.

Terdapat beberapa gejala yang dialami selama premenstrual syndrome (PMS) meliputi gejala perubahan fisik seperti sakit punggung, perut kembung, perubahan nafsu makan, pusing, pinsan, sakit kepala, susah tidur, kelainan kulit (berjerawatan), dan juga gejala psikis dan mental seperti mudah marah, tersinggung, cemas, depresi gelisah, sebentar sedih/ gembira, sulit berkonsentrasi dan pelupa ${ }^{8}$. Gejala tersebut menimbulkan dampak yang berpengaruh terhadap aktivitas penderita yang mengalami. Dampak yang dihasilkan dari premenstrual syndrome kepada remaja putri meliputi penurunan konsentrasi belajar dan penurunan aktivtas di sekolah ${ }^{4}$.

Determinan atau faktor-faktor yang berpengaruh terhadap premenstrual syndrome yaitu faktor genetik yang meliputi riwayat keluarga, faktor hormonal, faktor sosiodemografi yang meliputi umur, status perkawinan, pernah/ tidak melahirkan, pendidikan, pendapatan, usia menarche, tempat tinggal, faktor gaya hidup meliputi aktifitas fisik, pola konsumsi, faktor kimiawi meliputi perubahan kadar serotin ${ }^{9}$ Penelitian lain menyebutkan bahwa penyebab terjadinya gejala 
premenstrual syndrome yaitu interaksi yang kompleks antara hormon nutrisi esensial dan neurotransmitter yang dikombinasikan dengan stres psikologi ${ }^{10}$.

Salah satu faktor yang berhubungan dengan premenstrual syndrome (PMS) adalah usia menarche. Usia menarche yang dialami oleh setiap wanita sangat bervariasi antara umur 1216 tahun $^{1}$. Suatu penelitian menyebutkan ratarata usia menarche wanita yaitu 12 tahun $^{2}$. Usia menarche yang terjadi lebih cepat dan stress tinggi memiliki kontribusi terhadap kejadian premenstrual syndrome. Usia menarche $<12$ tahun berpeluang 6 kali lebih besar untuk terjadi premenstruasi sindrom ${ }^{11}$. Usia menarche juga berhubungan dengan status gizi yang ada pada remaja ${ }^{12}$.

Faktor status gizi memliki peranan yang cukup penting pada tingkat keparahan premenstrual syndrome. Penelitian sebelumnya menunjukkan obesitas memiliki keterkaitan dengan kejadian $\mathrm{PMS}^{13}$. Selain itu, di sebutkan juga bahwa setiap kenaikan $1 \mathrm{~kg} / \mathrm{m}^{2}$ pada IMT dikaitkan dengan peningkatan yang signifikan terhadap risiko premenstrual syndromesebesar $3 \%{ }^{14}$. Remaja putri yang mengalami PMS di Madrasah Aliyah Negeri 4 Jakarta yaitu $28,66 \%$, yang dipengaruhi oleh usia menarche dan tingkat stres ${ }^{11}$.

Pada saat remaja terjadi perubahan psikologis seperti emosi yang tidak stabil sehingga dapat mempengaruhi remaja dalam menghadapi dan memecahkan masalah. Keadaan tersebut menyebabkan remaja sulit memahami diri sendiri dan akan mendapatkan jalan buntu. Apabila masalah tidak ditangani maka akan menimbulkan stress pada remaja ${ }^{15}$.

Berdasarkan survey awal diketahui bahwa tidak ada yang mengganggap premenstrual syndrome sebagai suatu kondisi yang serius. Sebagian besar remaja putri menganggap bahwa premenstrual syndrome bukan suatu kondisi yang serius, sehingga tidak melakukan upaya pencegahan ataupun pengobatan. Hal ini sejalan dengan penelitian yang mengatakan bahwa seringkali PMS dianggap hal yang biasa saja pada beberapa orang sehingga tindakan yang dilakukan tidak merubah gaya hidup yang selama ini telah dijalankan, tetapi PMS sering kali merupakan suatu gangguan yang dapat berdampak menghambat aktivitas ${ }^{16}$. Premenstrual syndrome (PMS) dapat juga berubah menjadi kondisi yang serius seperti depresi.

Berdasarkan berbagai ulasan di atas, maka peneliti tertarik untuk mengetahui lebih mendalam tentang hubungan kejadian premenstrual syndrome dengan faktor-faktor yang dialami pada remaja putri di SMPN 7 Kota Jambi. SMPN 7 Kota Jambi memiliki jumlah siswi lebih banyak dibandingkan jumlah siswa yaitu 628 putri dan 478 putra. Di samping itu, belum ada penelitian tentang determinan yang berhubungan dengan kejadian premenstrual syndrome di daerah Jambi.

\section{METODE}

Jenis penelitian yang dilakukan bersifat observasional dengan menggunakan rancangan penelitian cross sectional dimana variabel dependen (premenstrual syndrome) dan variabel independen (usia menarche, status gizi dan stres) diteliti dalam waktu yang bersamaan. Tempat penelitian di SMPN 7 Kota Jambi. Waktu penelitian dari bulan November 2017Mei 2018. Populasi penelitian sebanyak 628 remaja putri dengan 93 sampel yang diambil secara stratified random sampling. Kriteria inkluasi yaitu siswa yang hadir di sekolah pada saat pengumpulan data, bersedia menjadi responden dan menandatangani inform consent, telah mengalami menstruasi minimal 1 bulan dan erusia 12-15 tahun (remaja awal). Instrumen penelitian yang digunakan yaitu Shortened Premenstrual Assessment Form (sPAF) menunjukkan test-retest reliability dari skala ini 0,80 dan konsistensi internal adalah 0,91 dan Self Roperting Qustionnaire (SRQ-20) yang 
telah di validasi oleh WHO serta alat ukur tinggi badan dan berat badan untuk pengukuran antropometri. Data dikumpulkan secara primer dengan melakukan wawancara dan obeservasi secara langsung. Hasil dari observasi untuk variabel status gizi menggunakan bantuan software WHO AntroPlus yang kemudian di kategorikan sesuai dengan standar antropometri

\section{HASIL}

\section{Karakteristik Responden}

Tabel 4.1

Distribusi Gambaran Umum Karakteristik Remaja Putri di SMPN 7 Kota Jambi

\begin{tabular}{lcccc}
\hline Karakteristik & Mean & Median & $\begin{array}{c}\text { Standar } \\
\text { deviasi }\end{array}$ & $\begin{array}{l}\text { Min- } \\
\text { Maks }\end{array}$ \\
\hline Umur & 13,34 & 13 & 0,950 & $\begin{array}{l}11-15 \\
\text { tahun }\end{array}$ \\
\hline Tinggi Badan & 153,4 & 153,5 & 5,779 & $\begin{array}{l}137,5- \\
168,9\end{array}$ \\
\hline Berat Badan & 48,8 & 46,6 & 9,485 & $\begin{array}{l}31,4- \\
79,3\end{array}$ \\
\hline PMS & 23,88 & 24 & 5,890 & $13-39$ \\
\hline $\begin{array}{l}\text { Usia } \\
\text { menarche }\end{array}$ & 11,7 & 12 & 0,842 & $10-15$ \\
\hline Stres & 7,97 & 8 & 2,887 & $1-16$ \\
\hline
\end{tabular}

Berdasarkan tabel diatas, diperoleh hasil bahwa rata-rata umur remaja putri yaitu 13 tahun dengan tinggi badan dan berat badan rata-rata $153,4 \mathrm{~cm}$ dan 48,8 $\mathrm{kg}$. Median dari PMS yaitu 24 poin sedangkan stres 8 poin. Usia paling cepat mengalami menarche yaitu 10 tahun dan paling lambat yaitu 15 tahun. Untuk lebih jelas mengenai distribusi frekuensi terhadap variabel dependen dan independen maka dapat terlihat pada tabel di bawah ini. oleh Kemenkes 2011. Teknik pengolahan data yang dilakukan yaitu tahapan editing, coding, entry dan cleaning. Analisis data yang digunakan meliputi analisis univariat untuk mengetahui gambaran PMS, stres dan status gizi remaja putri dan analisis bivariat untuk mengetahui hubungan antara vairabel independen dengan variabel dependen.

Tabel 4.2.

Distribusi Frekuensi Remaja Putri Berdasarkan Kejadian PMS, Usia Menarche, Status Gizi dan Stres di SMPN 7 Kota Jambi Tahun 2018

\begin{tabular}{|c|c|c|}
\hline Variabel & $\mathbf{n}$ & $\%$ \\
\hline $\begin{array}{l}\text { Premenstrual } \\
\text { (PMS) }\end{array}$ & & \\
\hline $\begin{array}{l}\text { Mengalami } \\
\text { mengalami berat }\end{array}$ & 27 & 29,03 \\
\hline $\begin{array}{l}\text { Tidak mengalami- } \\
\text { mengalami ringan }\end{array}$ & 66 & 70,96 \\
\hline \multicolumn{3}{|l|}{ Usia Menarche } \\
\hline Prekok & 4 & 4,30 \\
\hline Normal & 89 & 95,70 \\
\hline \multicolumn{3}{|l|}{ Status Gizi } \\
\hline Gemuk & 24 & 25,8 \\
\hline Normal & 69 & 74,2 \\
\hline \multicolumn{3}{|l|}{ Stres } \\
\hline Stres & 84 & 90,3 \\
\hline Tidak Stres & 5 & 9,7 \\
\hline
\end{tabular}

Berdasarkan tabel diketahui bahwa $29,03 \%$ yang mengalami gejala sedang-gejala berat. Usia menarche pada kategori prekok yaitu 4,30\%. Tidak terdapatnya status gizi kurus. Remaja putri yang mengalami stres yaitu $90,3 \%$.

\section{Gambaran Premenstrual Syndrom (PMS)}

Premenstrual Syndrom (PMS) adalah gejala-gejala yang dialami kurang lebih 7 hari sebelum menstruasi. Adapun jenis gejala yang dialami digambarkan pada tabel 4.3 berikut: 
Tabel 4.3

Distribusi Frekuensi Responden Berdasarkan Jenis Gejala Premenstrual Syndrome (PMS) pada Remaja Putri di SMPN 7 Kota Jambi Tahun 2018

\begin{tabular}{|l|c|c|c|c|c|c|c|c|}
\hline \multicolumn{1}{|c|}{$\begin{array}{c}\text { Jenis Gejala PMS yang } \\
\text { dialami }\end{array}$} & \multicolumn{2}{|c|}{$\begin{array}{c}\text { Tidak mengalami } \\
\text { (skor 1) \% }\end{array}$} & \multicolumn{2}{c|}{$\begin{array}{c}\text { Sangat ringan } \\
\text { hingga ringan } \\
\text { (skor 2-3) \% }\end{array}$} & \multicolumn{2}{c|}{$\begin{array}{c}\text { Sedang } \\
\text { (skor 4) \% }\end{array}$} & \multicolumn{2}{c|}{$\begin{array}{c}\text { Berat hingga } \\
\text { ekstra } \\
\text { (skor 5-6) \% }\end{array}$} \\
\hline & $\mathbf{n}$ & $\mathbf{\%}$ & $\mathbf{n}$ & $\mathbf{\%}$ & $\mathbf{n}$ & $\mathbf{\%}$ & $\mathbf{n}$ & \% \\
\hline Nyeri payudara & 42 & 45,1 & 30 & 32,2 & 18 & 19,3 & 3 & 3,2 \\
\hline Kewalahan atas persoalan & 38 & 40,9 & 32 & 34,4 & 18 & 19,4 & 5 & 5,4 \\
\hline Tertekan & 47 & 50,5 & 30 & 32,3 & 16 & 17,2 & 0 & 0 \\
\hline Mudah tersinggung & $\mathbf{1 2}$ & $\mathbf{1 2 , 9}$ & $\mathbf{2 5}$ & $\mathbf{2 6 , 9}$ & $\mathbf{3 2}$ & $\mathbf{3 4 , 4}$ & $\mathbf{2 4}$ & $\mathbf{2 5 , 8}$ \\
\hline Sedih, tak bersemangat & 39 & 41,9 & 24 & 25,9 & 25 & 26,9 & 5 & 5,4 \\
\hline Nyeri panggul & $\mathbf{3 5}$ & $\mathbf{3 7 , 6}$ & $\mathbf{2 9}$ & $\mathbf{3 1 , 2}$ & $\mathbf{1 9}$ & $\mathbf{2 0 , 4}$ & $\mathbf{1 0}$ & $\mathbf{1 0 , 8}$ \\
\hline Peningkatan Berat Badan & 19 & 20,4 & 43 & 46,3 & 25 & 26,9 & 6 & 6,5 \\
\hline Nyeri perut & $\mathbf{2 5}$ & $\mathbf{2 6 , 9}$ & $\mathbf{3 3}$ & $\mathbf{3 5 , 5}$ & $\mathbf{2 1}$ & $\mathbf{2 2 , 6}$ & $\mathbf{1 4}$ & $\mathbf{1 5 , 1}$ \\
\hline Adanya edema & 58 & $\mathbf{6 2 , 4}$ & 30 & 32,3 & 5 & 5,4 & 0 & 0 \\
\hline Perut kembung & 78 & 83,9 & 15 & 16,1 & 0 & 0 & 0 & 0 \\
\hline
\end{tabular}

Berdasarkan tabel 4.3 dapat diperoleh bahwa gejala PMS yang paling banyak dialami adalah mudah tersinggung yang memiliki persentase $87,1 \%$. Selain itu, terdapat tiga gejala PMS yang paling berat dialami yaitu mudah tersinggung yaitu 25,8\%, nyeri perut $15,1 \%$ (14 orang) dan nyeri panggul $10,8 \%$.

\section{Gambaran Stres}

Stres merupakan situasi dan kondisi yang menekan yang mengganggu emosional remaja putri yang meliputi gejala depresi, cemas, somatik, kognitif dan penurunan energi. Berikut hasil wawancara mengenai stres pada remaja putri:

Tabel 4.4

Distribusi Frekuensi Responden Berdasarkan Jenis Gejala Stres pada Remaja Putri di SMPN 7 Kota Jambi Tahun 2018

\begin{tabular}{|c|c|c|}
\hline \multirow[t]{2}{*}{ Pernyataan } & \multicolumn{2}{|c|}{ Ya } \\
\hline & $\mathbf{N}$ & $\%$ \\
\hline \multicolumn{3}{|l|}{ Depresi } \\
\hline 1. Merasa gugup, tegang atau cemas & 65 & 69,9 \\
\hline 2. Merasa tidak bahagia & 13 & 14,0 \\
\hline 3. Lebih sering menangis dari biasanya & 26 & 28,0 \\
\hline 4. Mampu melakukan hal-hal yang bermanfaat dalam hidup & 33 & 35,5 \\
\hline 5. Kehilangan minat pada berbagai hal & 44 & 47,3 \\
\hline 6. Merasa orang tak berguna & 36 & 38,7 \\
\hline 7. Mempunyai pikiran untuk mengakhiri hidup anda & 7 & 7.5 \\
\hline \multicolumn{3}{|l|}{ Cemas } \\
\hline 8. Tidur tidak nyenyak / terganggu & 24 & 25,8 \\
\hline 9. Mudah ketakutan & 24 & 25,8 \\
\hline 10. Apakah tangan anda gemetar & 42 & 45,2 \\
\hline \multicolumn{3}{|l|}{ Somatik } \\
\hline 11. Sering menderita sakit kepala & 36 & 38,7 \\
\hline 12. Nafsu makan anda berkurang & 16 & 17,2 \\
\hline 13. Pemceranaan terganggu / buruk & 10 & 10,8 \\
\hline 14. Mengalami rasa tidak enak perut & 43 & 46,2 \\
\hline \multicolumn{3}{|l|}{ Kognitif } \\
\hline 15. Sulit untuk berpikir jernih & 50 & 53,8 \\
\hline 16. Merasa sulit untuk membuat keputusan & 72 & 77,4 \\
\hline 17. Pekerjaan anda terganggu & 33 & 35,5 \\
\hline
\end{tabular}




\begin{tabular}{|l|l|l|}
\hline Penurunan Energi \\
\hline 18. Sulit menikmati kegiatan anda sehari-hari & 37 & 39,8 \\
\hline 19. Kelelahan sepanjang waktu & 64 & 68,8 \\
\hline 20. Mudah lelah & 66 & 71,0 \\
\hline
\end{tabular}

Berdasarkan tabel 4.4 diketahui bahwa terdapat lima gejala yang termasuk dalam kategori stres. Pada gejala depresi pertanyaan apakah anda merasakan gugup tegang atau cemas menduduki posisi yang paling banyak dialami oleh remaja putri yaitu 69,9\%. Pada gejala cemas dengan pertanyaan tangan yang gemetar yaitu $42,5 \%$ sedangkan pada gejala somatik dengan pertanyaan sering menderita sakit kepala yaitu 38,7 \%. Pada gejala kognitif dengan pertanyaan sulit membuat keputusan yaitu $77,4 \%$ sedangkan pada penurunan energi dengan pertanyaan mudah lelah yaitu $66 \%$.

\section{Analisis Bivariat}

Analisis bivariat dilakukan untuk mengetahui antara variabel dependen dan variabel independen. Untuk mempermudah dalam penyajian hasil, lihat tabel 4.5 di bawah ini:

Tabel 4.5

Analisis hubungan antara Variabel Dependen dan Variabel Independen pada Remaja Putri di SMPN 7 Kota Jambi

*Fisher Exact Test

\begin{tabular}{|c|c|c|c|c|c|c|c|c|c|}
\hline \multirow[t]{3}{*}{ Variabel } & \multicolumn{4}{|c|}{ PMS } & \multirow{2}{*}{\multicolumn{2}{|c|}{ Total }} & \multirow[t]{3}{*}{ P value } & \multirow[t]{3}{*}{ POR } & \multirow[t]{3}{*}{ IK 95\% } \\
\hline & \multicolumn{2}{|c|}{$\begin{array}{c}\text { Gejala sedang } \\
\text { s/d berat }\end{array}$} & \multicolumn{2}{|c|}{$\begin{array}{ll}\text { Tidak ada } & \text { s/d } \\
\text { gejala ringan } & \end{array}$} & & & & & \\
\hline & $\mathbf{n}$ & $\%$ & n & $\%$ & $\mathbf{n}$ & $\%$ & & & \\
\hline \multicolumn{7}{|c|}{ Usia menarche } & \multirow{3}{*}{$1,000 *$} & \multirow{3}{*}{0,808} & \multirow{3}{*}{$0,080-8,127$} \\
\hline Prekok & 1 & 25 & 3 & 75 & 4 & 100 & & & \\
\hline Normal & 26 & 29,7 & 63 & 70,8 & 89 & 100 & & & \\
\hline \multicolumn{2}{|l|}{ Status Gizi } & & & & & & \multirow{3}{*}{0,186} & \multirow{3}{*}{2,185} & \multirow[t]{3}{*}{$0,821-5,815$} \\
\hline Gemuk & 10 & 41,7 & 14 & 58,3 & 24 & 100 & & & \\
\hline Normal & 17 & 24,6 & 52 & 75,4 & 69 & 100 & & & \\
\hline Stres & & & & & & & \multirow{3}{*}{$0,276^{*}$} & \multirow{3}{*}{3,586} & \multirow[t]{3}{*}{$0,426-30,168$} \\
\hline Stres & 26 & 31,0 & 58 & 69,0 & 84 & 100 & & & \\
\hline Tidak Stres & 1 & 11,1 & 8 & 88,9 & 9 & 100 & & & \\
\hline
\end{tabular}

Berdasarkan tabel 4.5 diperoleh hasil dari 4 remaja putri yang mengalami usia menarche prekok, 25\% mengalami kejadian PMS dengan gejala sedang - gejala berat prekok $25 \%$ sedangkan dari 89 remaja putri yang mengalami menarche dengan usia normal, 29,7\% mengalami kejadian PMS dengan gejala sedang-gejala berat. Hasil uji statistik diperoleh nilai $\mathrm{p}$-value sebesar 1,000 dimana ( $>00,05)$ maka dapat disimpulkan tidak ada hubungan antara premenstrual syndrome (PMS) dengan usia menarche pada remaja putri di SMPN 7 Kota Jambi tahun 2018.

Pada variabel status gizi diperolah dari 24 remaja putri yang status gizi gemuk, 41,7\% mengalami kejadian PMS gejala sedang-gejala berat sedangkan dari 69 remaja putri yang status gizi normal, 24,6\% mengalami kejadian PMS gejala sedang sampai gejala berat. Hasil uji statistik diperoleh nilai $\mathrm{p}$ value sebesar 0,186 dimana ( $\mathrm{p}$-value >0,05) maka dapat disimpulkan bahwa tidak ada hubungan antara status gizi dengan Premenstrual Syndrom (PMS) dengan pada remaja putri di SMPN 7 Kota Jambi tahun 2018. Nilai POR yaitu 2,185 yang berarti status gizi gemuk beresiko 2 kali lebih menyebabkan PMS walaupun tidak signifikan.

Berdasarkan tabel tersebut juga diketahui bahwa dari 84 remaja putri yang mengalami gejala stres, 31,0\% mengalami kejadian PMS gejala sedang-berat sedangkan, dari 9 remaja 
putri yang tidak mengalami gejala stres, $11,1 \%$ mengalami kejadian PMS dengan gejala sedangberat. Hasil analisis uji statistik diperoleh nilai p-value yaitu 0.276 dimana pvalue $>0.05$ maka tidak ada hubungan antara stres dengan PMS pada remaja putri di SMPN 7 Kota Jambi tahun 2018. Stres cenderung menyebabkan 3,586 kali terkena PMS sedang-berat.

\section{PEMBAHASAN}

\section{Hubungan antara Usia Menarche dengan PMS pada Remaja Putri di SMPN 7 Kota Jambi}

Berdasarkan hasil uji chi square diperoleh nilai $\mathrm{p}$-value sebesar 1,000 dimana ( $\mathrm{p}>0,005)$ maka dapat disimpulkan tidak ada hubungan antara premenstrual syndrome (PMS) dengan usia menarche pada remaja putri di SMPN 7 Kota Jambi. Data menyebutkan bahwa dari 89 remaja putri terdapat $70,8 \%$ yang berada dalam usia menarche normal dan tidak mengalamimengalami gejala ringan.

Menarche merupakan penanda utama seorang wanita telah memasuki ciri maturitas seksual. Hal ini dikarenakan menarche merupakan salah satu indikator tahap pubertas pada remaja ${ }^{17}$. Apabila remaja putri telah mengalami menarche (menstruasi pertama) maka dapat disimpulkan bahwa remaja tersebut telah memasuki masa pubertas.

Onset usia menarche sangat berhubungan dengan jumlah persentase lemak tubuh ${ }^{18}$. Akhirakhir ini telah diketahui bahwa terdapat dua tanda metabolik yang dapat bekerja secara sentral dan merupakan penyebab peristiwaperistiwa pada pubertas yaitu IGF-I dan leptin. Kadar IGF-I dalam serum meningkat selama masa kanak-kanak dan memuncak saat terjadi pubertas: peningkatan ini bersamaan dengan DHEA-S yang merupakan penanda adrenarke. Leptin, sebuah hormon yang merupakan tanda dari rasa kenyang, bekerja menghambar neuropeptida-Y (NPY). NPY merupakan mediator pada asupan makanan dan mengontrol aktivtas GnRH di hipotalamus.

Pada tahun-tahun pertama setelah menarche, banyak terjadi siklus menstruasi yang anovulatoir. Ini menggambarkan kurang matangnya respons umpan balik positif hipotalamus terhadap estrogen ovarium. Pola pendarahan saat menstruasi seringkali terjadi lebih awal setelah menarche yang menggambarkan paparan estrogen yang terus menerus pada ovarium dan peluruan endometrium yang berpoliferasi atau hiperplastik. Karena tidak terbentuknya korput luteum pada keadaan anovulasi, endometrium tidak dapat memperlihatkan efek progesteron yang membuat menstruasi menjadi fenomena yang berhenti sendiri. Pendarahan anovulatoir ini dapat tidak terduga dan sangat parah. Setelah 5 tahun sejak onser menarche, 90\% anak perempuan akan mengalami siklus menstruasi yang teratur dan ovulatoir ${ }^{18}$.

Penelitian ini sejalan dengan penelitian yang juga menemukan bahwa tidak ada hubungan antara usia menarche dengan $\mathrm{PMS}^{19-}$ 20. Mekanisme antara usia menarche yang dikaitkan dengan PMS sebenarnya masih belum jelas $^{21}$. Hal ini menyebabkan tidak adanya alasan yang jelas pada keempat penelitian sebelumnya terkait tidak adanya hubungan antara usia menarche dengan PMS. Penelitian lain menyebutkan bahwa kemungkinan asosiasi antara usia menarche dan gejala-gejala PMS dapat diselidiki dengan mengendalikan beberapa faktor pembaur potensial (yang tidak disebutkan $)^{22}$. Namun penelitian ini tidak sejalan dengan penelitian Amjad tahun 2014 yang menemukan adanya hubungan antara usia menarche dengan $\mathrm{PMS}^{21}$. Hasil penelitian Amjad tahun 2014 menemukan bahwa usia menarche $<12$ tahun cenderung mengalami $\mathrm{PMS}^{21}$.

Berdasarkan penjelasan-penjelasan diatas peneliti menyimpulkan bahwa walaupun hasil penelitian ini menunjukkan secara statistik tidak 
ada hubungan, namun berdasarkan tabel distribusi frekuensi terlihat bahwa perbedaan antara menarche normal dan prekok tidak jauh berbeda hanya 4,7\% dimana usia menarche prekok $25 \%$ yang mengalami gejala sedangberat dan usia menarche normal 29,7\%yang mengalami gejala sedang-berat.

Peneliti juga berasumsi bahwa tidak ada hubungan antara usia menarche dengan PMS dikarenakan tidak adanya mekanisme yang jelas antara usia menarche dengan PMS. Selain itu, pernyataan teori yang mengatakan bahwa siklus menstruasi berkaitan dengan usia menarche menguatkan asumsi peneliti bahwa menarche berkaitan dengan siklus menstruasi dimana remaja putri di SMPN 7 belum sampai 5 tahun mengalami menstruasi. Selain itu persentase lemak dalam tubuh juga berpengaruh terhadap menarche.

\section{Hubungan Status Gizi dengan Kejadian PMS}

Berdasarkan hasil uji chi square $\mathrm{p}$ value sebesar 0,186 . Nilai p-value 0,186 menunjukkan bahwa tidak ada hubungan antara status gizi (IMT/U) dengan Premenstrual Syndrom (PMS) pada pemaja Putri di SMPN 7 Kota Jambi. Remaja putri dengan status gizi gemuk yang mengalami gejala sedang-berat yaitu $41,7 \%$ sedangkan yang mengalami tidak ada gejalagejala ringan yaitu 58,3\%. Indeks Massa Tubuh tidak berhubungan dengan kejadian PMS namun ada kecenderungan nilai POR meningkat dengan bertambahnya IMT. Nilai POR yang diperoleh yaitu 2,185 dimana berarti status gizi gemuk beresiko untuk meningkatkan 2, 185 kali lebih beresiko terkena PMS dengan gejala sedang s/d gejala berat.

Definisi gizi dalam kesehatan reproduksi adalah bagaimana seorang individu, mampu untuk mencukupi kebutuhan gizi yang diperlukan oleh tubuhnya, agar individu tersebut tetap berada dalam keadaan sehat baik secara fisik atau mental, serta mampu menjalankan sistem metabolisme dan reproduksi baik fungsi atau prosesnya secara alamiah dengan keadaan tubuh yang sehat ${ }^{23}$. Status gizi adalah keadaan yang diakibatkan karena seimbang dan tidaknya jumlah asupan dan jumlah zat gizi yang dibutuhkan oleh tubuh untuk berbagai fungsi biologis, seperti pertumbuhan fisik, perkembangan, aktivitas atau produktivitas, pemeliharaan kesehatan dan lainnya ${ }^{24}$.

Hasil penelitian yang dilakukan oleh menemukan bahwa tidak terdapat hubungan antara status gizi dengan PMS dikarenakan hasil ukur yang berbeda dimana Aminah pada tahun 2011 menggunakan hasil ukur normal dan tidak normal sehingga hasil penelitiannya menunjukkan bahwa tidak berhubungannya mungkin dapat dikarenakan tidak adanya siswi yang memiliki status gizi obesitas ${ }^{11}$. Penelitian sejalan juga dilakukan oleh Nurmiaty pada tahun 2011 bahwa tidak ada hubungan antara variabel IMT dengan $\mathrm{PMS}^{19}$. Namun secara praktis cukup signifikan. Asupan gizi dengan penambahan 4 gram lemak akan meningkatkan 2,1 kali resiko terjadinya PMS. Peningkatan asupan karbohidrat 25 gram akan meningkatkan resiko 2,8 kali PMS ${ }^{19}$.

Penelitian tidak sejalan yang dilakukan Supriyono didapatkan hasil bahwa IMT berhubungan dengan PMS dimana hormon insulin juga ikut berperan dalam hubungan antara IMT dan $\mathrm{PMS}^{25}$. Presentase lemak dalam tubuh yang mengakibatkan perubahan sensitivitas dan sekresi insulin sehingga kadar insulin dalam darah jadi meningkat. Kadar insulin yang meningkat ini secara langsung menurunkan sex-hormone binding globulin (SHBG) dimana SHBG ini berfungsi untuk menekan hormon androgen. Jika SHBG turun maka fungsinya untuk menekan androgen juga turun, yang mengakibatkan kadar androgen dalam tubuh akan tinggi sehingga akan timbul gejala-gelaja PMS . Menurut hasil penelitiannya menghasilkan kesimpulan bahwa wanita dengan IMT berlebih cenderung akan mengalami PMS, 
dibuktikan dengan mempunyai resiko 43,432 kali terjadi PMS, sedangkan berat badan normal cenderung mempunyai proteksi terhadap kejadian $\mathrm{PMS}^{25}$.

Penelitian lain dikota Jambi bahwa ada hubungan yang signifikan antara obesitas dengan siklus menstruasi pada remaja putri ${ }^{26}$. Hal tersebut terlihat pada berat badan yang obesitas mempunyai peluang 1,97 kali lipat mengalami gangguan siklus menstruasi dibandingkan dengan berat badan tidak obestitas $^{26}$. Lemak tubuh mempengaruhi siklus menstruasi. Sel adiposa mempengaruhi estrogen wanita obesitas, sirkulasi estrogen sangat besar dibanding wanita normal ${ }^{19}$. Namun, $90 \%$ siklus menstruasi pada remaja akan teratur apabila telah mencapai 5 tahun $^{18}$.

Berdasarkan penjesan diatas peneliti menyimpulkan terdapat beberapa alasan yaitu gambaran umum remaja putri di SMPN 7 74,2\% berkategori normal yang tidak beresiko terhadap terjadinya PMS. Selain itu, remaja putri di SMPN 7 Kota Jambi belum mencapai 5 tahun telah melewati masa menstruasi pertama.

\section{Hubungan antara Stres dengan PMS}

Berdasarkan hasil uji chi square p-value sebesar 0, 276 dimana (p-value >0.05) maka dapat disimpulkan bahwa tidak ada hubungan antara Premenstrual Syndrom (PMS) dengan stres pada remaja putri di SMPN 7 Kota Jambi. Remaja putri yang tidak mengalami stres dan tidak mengalami sampai mengalami ringan gejala PMS yaitu $88,9 \%$ sedangkan remaja putri yang mengalami stres dan mengalami sedang sampai berat gejala PMS yaitu 31,0\%. Nilai POR yang didapatkan yaitu 3,586 yang menujukkan bahwa stres beresiko untuk meningkatkan kejadian PMS gejala sedang s/d berat sebanyak 3,586 kali.

Stres sangat diperlukan dalam kehidupan, karena bertindak sebagai energizer sehingga kita tumbuh dan berkembang menuju arah kedewasaan. Proses ini memerlukan rangsangan/ stresor dengan tingkat yang sedang sehingga kita mampu mengelola stresor tersebut dengan baik ${ }^{27}$.

Pada masa remajalah terjadi perubahanperubahan yang sangat berarti dalam segi fisiologis, emosional, sosial,dan intelektual. Perubahan fisik pada remaja terutama organorgan seksual memengaruhi berkembangnya emosi atau perasaan-perasaan dan dorongandorongan yang baru dimana sebelumnya tidak pernah di alami, seperti perasaan cinta, rindu yang sering kali menjadi malapetaka bagi perkembangan remaja selanjutnya ${ }^{28}$.

Dalam menyelesaikan masalah, setiap orang mempunyai pendekatan yang berbeda dari sisi sudut pandang yaitu problem focused coping dan emotional focused coping ${ }^{27}$. Problem focused coping adalah pemecahan masalah yang terfokus pada masalah yang dihadapi dan berusaha memperbaiki sedangkan emotional focused coping merupakan seseorang tersebut akan fokus terhadap emosi yang dialami selama stres berlangsung tanpa melakukan action apapun.

Beberapa strategi dalam menghadapi stres secara mental yaitu mempersiapkan diri menghadapi stres dimana hal ini berkaitan dengan olah pikir yang kita terapkan. Strategi selanjutnya adalah penetapan tujuan hidupdengan membuat skala prioritas yang akan dicapai sehingga kita akan lebih bersemangat dalam melaksanakan kegiatan sehari-hari. Strategi selanjutnya yaitu pengaturan waktu yang baik diman dapat dilakukan dengan membuat susunan jadwal yang akan dikerjakan setiap harinya sehingga waktu yang ada dapat terjalankan dengan efektif ${ }^{27}$.

Teori berbeda menyatakan bahwa remaja yang cenderung mengalami stres dalam kehidupan sehari-hari juga berhubungan dengan frekuensi gejala premenstruasi. Remaja dengan skor gejala premenstruasi tinggi, dilaporkan lebih banyak yang mengalami stres mental sedang atau tinggi ${ }^{29}$. Stres menyebabkan 
penyimpangan pada pengeluaran beta-endorphin yang dapat menyebabkan beberapa gejala PMS. Endorphin berfungsi mengatur berbagai fungsi fisiologi seperti transmisi nyeri, emosi, kontrol napsu makan dan sekresi hormon. Perubahan kadar endorphin memberikan efek penting pada mood dan perilaku ${ }^{30}$.

Hasil penelitian sejenis tentang daya tahan stress dan Premenstrual Syndrome (PMS) pada mahasiswi program A PSIK FK-UGM bahwa ada perbandingan yang mencolok antara individu yang memiliki daya tahan stress rendah dengan daya tahan stress tinggi dan 100\% responden mengalami PMS ringan. Hal ini menunjukkan bahwa meskipun mengalami PMS tetapi stressor itu bukan hal yang menggangu aktivitas sehari-harinya ${ }^{31}$. Penelitian lain yang bertentang yaitu penelitian yang dilakukan oleh Nurmiaty yang mengungkpankan bahwa tingkat stres berpengaruh terhadap PMS ${ }^{19}$.

Berdasarkan penjelasan diatas, peneliti menyimpulkan bahwa tidak adanya hubungan antara variabel stres dengan variabel PMS dikarenakan presentase kategori tidak stres dan tidak ada gejala hingga gejala ringan PMS lebih besar yaitu $88,9 \%$ sedangkan persentase kategori stres dan tidak mengalami PMS sebesar

\section{KESIMPULAN}

1. Sebanyak $71 \%$ remaja putri di SMPN 7 Kota Jambi yang tidak mengalami gejala PMS sampai mengalami ringan. Gejala yang paling banyak yaitu mudah tersinggung $87,1 \%$.

2. Sebanyak $4,3 \%$ remaja putri di SMPN 7 Kota Jambi mengalami usia menarche prekok dengan 25,8\% memiliki status gizi gemuk dan 90,3\% remaja putri di SMPN 7 Kota Jambi mengalami gejala stres.

3. Tidak terdapat hubungan antara PMS dengan usia menarche pada remaja putri di SMPN 7 Kota Jambi $($ POR $=0,808$, IK $95 \%=0,080-8,127)$.
69,0\%. Selain itu, presentase kategori stres dan tidak mengalami PMS yang tinggi dapat terjadiasumsikan karena remaja putri yang dapat mengatasi stresnya dengan cara yang baik. Menurut teori bahwa dalam penanganan/ manajemen stres seseorang dapat membuat dirinya semakin kearah positif ataupun kearah negatif.

Peneliti juga berasumsi bahwa remaja putri di SMPN 7 Kota Jambi menerapkan pendekatan/ sudut pandang problem focused coping dimana pemecahan masalah terfokus pada masalah yang dihadapi. Hal tersebut dapat terlihat pada persentase yang tinggi sebesar 92,5\% remaja putri yang tidak terpikir untuk mengakhiri hidup atas setiap permasalahan yang dihadapinya.

Asumsi lain yang dihasilkan peneliti bahwa remaja putri di SMPN 7 mampu untuk mengelola stresor tersebut dengan sangat baik sehingga tidak berhubungan dengan PMS. Remaja putri sangat aktif dalam setiapkegiatan ekstrakulikuler. Ada banyak sekali kegiatan ekstrakulikuler yang diminati di SMPN 7 seperti PMR, traditional dance, hiphop dance, basket, musik dan banyak lainnya.

4. Tidak terdapat hubungan antara PMS dengan status gizi pada remaja putri di SMPN 7 Kota Jambi, namun terdapat kecenderungan bahwa status gizi gemuk 2,185 kali beresiko terhadap PMS sedangberat.

5. Tidak terdapat hubungan antara PMS dengan gejala stres pada remaja putri di SMPN 7 Kota Jambi, namun terdapat kecenderungan bahwa stres memilik 3,586 kali beresiko terhadap PMS sedang-berat.

\section{SARAN}

1. Diharapkan pihak SMPN7 mampu mengoptimalkan fungsi dari Unit Kesehatan 
Sekolah (UKS) dalam promosi dan pencegahan masalah kesehatan

2. Diharapkan remaja putri mampu mengetahui siklus menstruasi sehingga ada persiapan untuk menghadapi menstruasi.

3. Diharapkan remaja putri mampu memahami dan melaksanakan Pedoman Gizi Seimbang (PGS).

4. Diharapkan remaja putri melakukan aktivitas sehari-hari dan melakukan penyegaran setiap paginya sebelum memulai proses belajar dengan melakukan streching .

\section{DAFTAR PUSTAKA}

1. Proverawati, A., \& Misaroh, S. 2009. Menarche Menstruasi Pertama Penuh Makna. Yogyakarta: Nuha Medika

2. Rusmini, dkk. 2017. Pelayanan KB dan Kesehatan Reproduksi. Jakarta : Trans Info Media

3. Zuhana, Nina. 2016. Hubungan Usia Menarche dengan Kejadian Sindrom Pramenstruasi di SMP Negeri 1 Sragi Kabupaten Pekalongan tahun 2016. Stikes Muhammadiyah Pekajangan Pekalongan

4. Suparman . 2011. Premenstrual Syndrome. Jakarta : EGC

5. Moghadam, A. D.,dkk. 2014. Epidemiology of Premenstrual Syndrome (PMS)-A Systematic Review and Meta-Analysis study. Journal of Clinical and Diagnostic Research: JCDR, 8, 106-109

6. Siantina, Ressa. 2010. Hubungan Antara Asupan Zat Gizi dan Aktivitas Olahraga dengan Kejadian PMS pada Remaja Putri di SMAN 1 Padang tahun 2010. Fakultas Keperawatan, Universitas Andalas

7. Aldira, C. F. 2014. Hubungan Aktivitas Fisik dan Stres dengan Sindrom Pramenstruasi pada Remaja Putri di SMA Bina Insani Bogor. Skripsi, Institut Pertanian Bogor

8. Haryono, Rudi. 2016. Siap Menghadapi Menstruasi \& Menopause. Yogyakarta: Gosyen Publishing

9. Saryono dan Sejati. 2009. Sindrom Premenstruasi. Yogyakarta: Nuha Medika
5. Diharapkan remaja putri aktif mengikuti PIK-R dan UKS sebagai upaya untuk preventif dan promotif serta jika mengalami masalah dapat berkonsultasi dengan Bimbingan Konseling (BK).

6. Diharapkan peneliti selanjutnya dapat melakukan penelitian dengan menggunakan desain penelitian lain, seperti case control study dan menambah variabel pola makan, pola tidur, aktvitas fisik, asupan zat gizi dan riwayat keluarga yang berhubungan dengan kejadian PMS.

10. Rusfiana, Annisa dkk. 2016. Hubungan Premesntruasi Syndrome (PMS) terhadap Faktor Psikologis pada Remaja. Universitas Lampung. Majority, Volume 5 Nomor 1 Tahun 2016

11. Aminah, Siti W, dkk. 2011. Hubungan Status Gizi dengan Kejadian Premenstrual Syndrome di Madrasah Aliyah Negeri (MAN ) 4 Jakarta Tahun 2011. Jurnal Kesehatan Volume 2, Nomor 3, Nopember 2011, ISSBN 1978-4325

12. Dieny. 2014. Permasalahan Gizi pada Remaja Putri. Yogyakarta: Graha Ilmu

13. Masho, S., dkk. 2005. Obesity as a Risk Factor for Premenstrual Syndrome. J Psychocom Obstet Gynaecol, 26,6

14. Johnson, E. R. B., dkk. 2010. Adiposity and the Development of Premesntrual Sydnrome. J. Womens Health (Larchmt). 19,7

15. Magfiroh, Isni Lailatul dkk, 2011. Hubungan Tingkat Stress dengan Kejadian Oligomenorrhea Pada Santriwati Pondok Pesantren Al-Mizan Muhammadiyah Lamongan Tahun 2011. Surya (Jurnal Meida Komunikasi Ilmu Kesehatan) diterbitkan oleh Sekolah Tinggi Ilmu Kesehatan (STIKES) Muhammadiyah Lamongan. Vol. 03, NO. X Des 2011

16. Wahyuni, Lusi dkk. 2015. Tipe dan Cara Mengatasi Pre Menstruasi Sindrom Pada Mahasiswi Kebidanan Unmuh Surabaya

17. Almatsier, dkk. 2011. Gizi seimbang dalam Dasar Kehidupan. Jakarta: PT. Gramedia Pustaka Utama 
18. Heffner, dkk. 2008. At a Glance Sistem Reproduksi. Jakarta: Erlangga

19. Nurmiaty, Wilopo,S.A. dan Sudargo, T. 2011. Perilaku Makan dengan Kejadian Sindrom Premenstruasi pada Remaja. Berita Kedokteran Masyarakat Vol. 27 No, 2 Juni 2011

20. Tambing, Y. 2012. Physical Activity and Premenstrual Syndrome in Teenagers. Thesis. Universitas Gajah Mada

21. Amjad, A., dkk. 2014. Socio-demographic factors and Premenstrual Syndrome among Women attending a Teaching Hospital in Islamabad Pakistan. J. Pionneer Med Sci, 4,4

22. Silva, C. M. L. D., Gigante, D. P. dan Minten, G. C. 2008. Prementrual Symtoms and SyndromeAccording to Age at Menarche in a 1982 Birth Cohort in Southern Brazil. Cad. Saude Publica, Rio de Janeiro, 24, 10 https://www.scielosp.org/pdf/csp/2008.v24n4/8 $\underline{35-844 / \mathrm{en}}$

23. Marmi. 2015. Kesehatan Reproduksi. Yogyakarta: Pustaka Pelajar

24. Depkes. 2006. Glosarium: Data dan Informasi Kesehatan. Jakarta: Pusat Data dan Informasi Depkes RI

25. Supriyono, B. 2003. Hubungan Indeks Massa Tubuh dengan Sindroma Prahaid. Tesis. http://eprints.undip.ac.id/122 80/1/2003FK140110342.pdf

26. Harahap, Irmayanti. 2012. Hubungan Indeks Massa Tubuh (IMT) terhadap Siklus Menstruasi pada Remaja Putri di SMPN 17 Kota Jambi Tahun 2012. Scienta Journal. Vol.2 No.1Mei 2013

27. Chomaria. 2018. Kenali Masa Remaja Anak: Membangun Keahlian Pribadi. Solo: Tiga Serangkai

28. Nurichsan, dkk. 2016. Dinamika Perkembangan Anak dan Remaja: Tinjauan Psikologi, Pendidikan dan Bimbingan. Bandung: PT. RefikaAditama

29. Rasheed. 2003. Prevalence and predictors of premenstrual syndrome among college-aged women in Saudi Arabia. https://europepmc.org/abstract/med/16868373

30. Mayo, Joseph L. 1999. Premenstrual Syndrome: A Natural Approach to Management. Nutricional Science Report.
http://www.comilac.com.tr/uploads/pdf/24Com FUGA.pdf

31. Aida.2003. Daya Tahan Stress dan Premenstrual Syndrome Pada Mahasiswi Program A PSIK FK-UGM. Skipsi, Program Sarjana Keperawatan UGM.Yogyakarta 